\title{
High-performance liquid chromatographic analysis of the antitumour drug camptothecin and its lactone ring-opened form in rat plasma
}

\author{
J. H. Beijnen* \\ Hospital, Plesmanlaan 121, 1066 CX Amsterdam (Netherlands)

\section{H. Rosing} \\ Slotervaart Hospital, Louwesweg 6, 1066 EC Amsterdam (Netherlands)
}

Slotervaart Hospital, Louwesweg 6, 1066 EC Amsterdam (Netherlands) and Netherlands Cancer Institute/Antoni van Leeuwenhoek

\author{
W. W. ten Bokkel Huinink and H. M. Pinedo \\ Netherlands Cancer Institute/Antoni van Leeuwenhoek Hospital, Plesmanlaan 121, 1066 CX Amsterdam (Netherlands)
}

(First received February 1st, 1993; revised manuscript received April 26th, 1993)

\begin{abstract}
A sensitive high-performance liquid chromatographic (HPLC) method is described for the simultaneous determination of the antitumour drug camptothecin (I) and its lactone ring-opened form (II) in plasma. The sample pretreatment involved protein precipitation with cold methanol $\left(-30^{\circ} \mathrm{C}\right)$. The methanolic extract was injected directly onto the HPLC column. Chromatography was carried out with a LiChrosorb RP-18 column (particle size $5 \mu \mathrm{m}$ ) and a mobile phase composed of methanol-phosphate buffer $(5 \mathrm{~m} M$, pH 6.5)-0.3 $M$ tetrabutylammonium phosphate solution (500:500:15, v/v/v). The column effluent was monitored spectrofluorimetrically with the excitation wavelength set at $369 \mathrm{~nm}$ and the emission wavelength at $426 \mathrm{~nm}$. The chemical stabilities of camptothecin and the ring-opened form in aqueous solutions, in plasma and after methanolic extraction, were investigated. The proposed method was validated and utilized in pharmacokinetic studies with rats.
\end{abstract}

\section{INTRODUCTION}

Camptothecin, a plant alkaloid isolated from Camptotheca acuminata [1], is the prototype of a novel class of antitumour agents which exert their activities exclusively by inhibition of topoisomerase I [2]. Topoisomerases are intranuclear enzymes that transiently break and rejoin DNA

\footnotetext{
* Corresponding author. Address for correspondence: Slotervaart Hospital, Louwesweg 6, 1066 EC Amsterdam, Netherlands.
}

strands to facilitate processes like replication, recombination and transcription, essential for cell survival. During the initial phase I trials some promising responses were seen in colorectal carcinomas, non-small-cell lung cancer, melanoma and acute myeloid leukemia [3-5]. Unfortunately, further clinical evaluation of camptothecin had to be discontinued due to its unpredictable toxicity profile including myelosuppression, gastrointestinal toxicity and haemorrhagic cystitis [6]. Its poor water solubility was a problem in the pharmaceutical formulation of the drug and was 

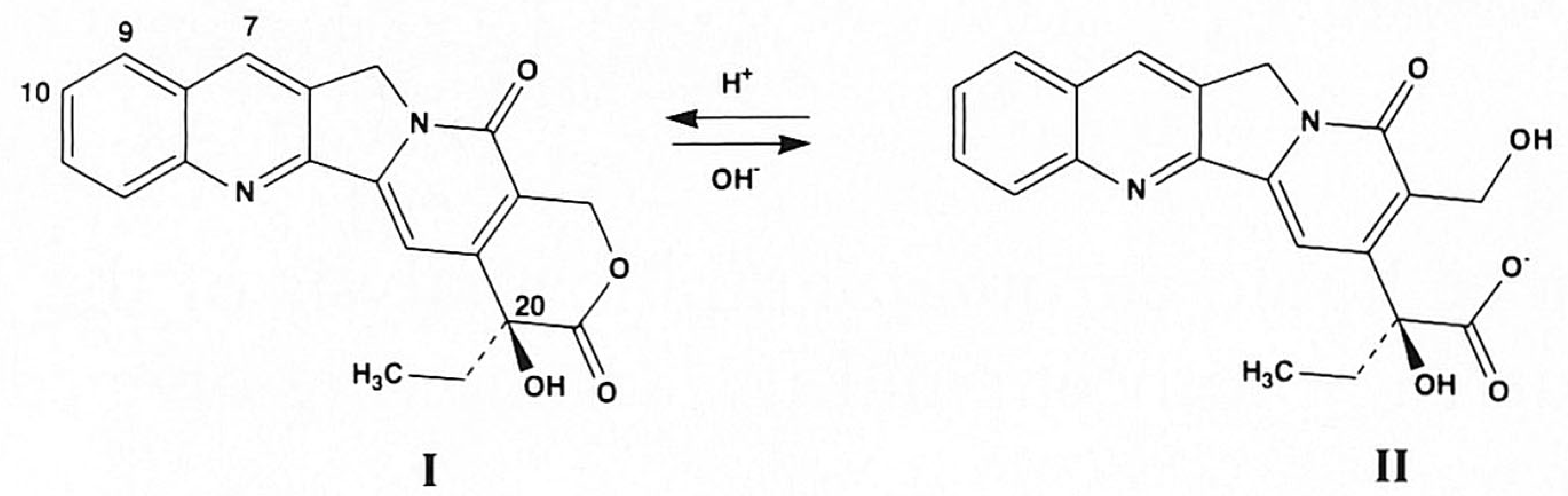

Fig. 1. Structures of and equilibrium reactions between camptothecin (I) and the ring-opened carboxylate form (II).

considered to be the cause of the bladder toxicity.

Recently, new semi-synthetic analogues have been developed from which topotecan (9-dimethylaminomethyl-10-hydroxycamptothecin; NSC 609669) [7] and CPT-11 (7-ethyl-10-[4-(1-piperidyl)-1-piperidyl]carbonyloxycamptothecin) are now clinically tested in phase II trials. Another camptothecin derivative, 9-aminocamptothecin (NSC 603071), is at an earlier stage of development [9]. The new derivatives have in common that they are more water-soluble than the parent compound camptothecin. Chemically this class of compounds is characterized by a heterocyclic five-ring structure and a C-20 $(S)$ tertiary alcohol function adjacent to the lactone carbonyl group (Fig. 1). This lactone function is essential for the activity of camptothecin and its analogues. The lactone hydrolysed form exhibits only a minimal topoisomerase I inhibitory activity [10]. At physiological $\mathrm{pH}$, however, the lactone function is not stable and equilibrium processes favour hydrolysis to yield the hydroxy acid. In acid solution the reverse reaction with the formation of the lactone is favoured (Fig. 1). A kinetic and mechanistic study of these processes has recently been published by Fassberg and Stella [11].

The enormous current interest in topoisomerase I inhibitors has revived research with the parent compound camptothecin in particular in preclinical investigations where the drug is used as a reference topoisomerase I inhibitor [9]. So far, only a few methods have been reported for the analysis of camptothecin in biological fluids $[3,5,12,13]$. Reported assays include total fluorescence or ultraviolet measurements $[3,13]$ in com- bination with thin-layer chromatography [5] or HPLC [12]. In all cases the samples are acidified to $\mathrm{pH} 2$ and extracted with ethyl acetate $[12,13]$ or toluene [3] prior to analysis. In these assays, however, only total drug levels are determined which provide no information about the ratio between the active lactone (I) and the inactive hydrolysed form (II) of camptothecin. This report describes a simple and sensitive HPLC assay for the simultaneous determination of both species in plasma.

\section{EXPERIMENTAL}

\section{Materials}

Camptothecin (NSC 94600) and the sodium salt of camptothecincarboxylate (NSC 100880) were obtained from the National Cancer Institute (Bethesda, MD, USA) and used without further purification. All reagents were of analytical grade, and double-distilled water was used throughout. Plasma was obtained by cardiac puncture from WAG/Rij rats.

\section{Chromatography}

The chromatographic system comprised a Type 6000 A solvent delivery system (Waters Assoc., Milford, MA, USA), a Model SP 8880 automatic sample injection device (Spectra Physics, Santa Clara, CA, USA) and an LS 40 fluorescence detector (Perkin-Elmer, Beaconsfield, UK) equipped with a $7-\mu$ l flow cell. The analytical column (125 mm $\times 4 \mathrm{~mm}$ I.D.) was packed with LiChrosorb RP-18 material (particle size $5 \mu \mathrm{m}$ ) (Merck, Darmstadt, Germany). The analytes 
were eluted isocratically with a mobile phase composed of methanol-5 $\mathrm{m} M$ phosphate buffer (pH 6.5)-0.3 $M$ tetrabutylammonium phosphate solution $(500: 500: 15, \mathrm{v} / \mathrm{v} / \mathrm{v})$. The $0.3 M$ tetrabutylammonium phosphate solution (PIC-A reagent) was purchased from Waters Assoc. The flow-rate was $1.0 \mathrm{ml} / \mathrm{min}$ with the column at ambient temperature. The column effluent was monitored spectrofluorimetrically with the excitation wavelength at $369 \mathrm{~nm}$ and the emission wavelength at $426 \mathrm{~nm}$. Retention times and peak areas were measured with an SP-4290 integrator which is part of a WINner/286 data system (both from Spectra Physics).

\section{Sample pretreatment}

The analytes were isolated from plasma by methanol extraction with protein precipitation. For the isolation of I and II, 100- $\mu$ l plasma samples, in polypropylene Eppendorf tubes, were mixed with $400 \mu$ l of cold methanol $\left(-30^{\circ} \mathrm{C}\right)$ and vortex-mixed for $10 \mathrm{~s}$. After centrifugation $(2 \mathrm{~min}$ at $9500 \mathrm{~g}$ ) the clear supernatant was transferred to a clean glass autosampler vial and injected directly onto the HPLC column or stored at $-30^{\circ} \mathrm{C}$ prior to analysis. For analysis, an aliquot of $100 \mu \mathrm{l}$ (for the $1-10 \mathrm{ng} / \mathrm{ml}$ range) or $25 \mu \mathrm{l}$ (for the $10-1000 \mathrm{ng} / \mathrm{ml}$ range) was injected into the HPLC system.

\section{Calibration}

For calibration, blank plasma samples $(100 \mu \mathrm{l})$ were spiked with $0-100 \mu \mathrm{l}$ of solutions of I or II. Stock solutions of I $(10 \mu \mathrm{g} / \mathrm{ml}$, in methanol $)$ and II $(50 \mu \mathrm{g} / \mathrm{ml}$, in a mixture of methanol-water, $1: 1$, $\mathrm{v} / \mathrm{v}$ ) were diluted with methanol to obtain the appropriate concentrations. Cold methanol $\left(-30^{\circ} \mathrm{C}\right)$ was then added to the plasma calibration samples up to a total volume of $500 \mu \mathrm{l}$. The samples were further processed as described under Sample pretreatment.

\section{Validation}

Linearity of the assay was investigated by analysing spiked plasma samples. Recoveries of I and II from plasma samples were determined by comparison of peak areas of the plasma extracts and known amounts of I and II added to $100 \mu \mathrm{l}$ of water supplemented with cold methanol up to a total volume of $500 \mu \mathrm{l}$. Precision and accuracy were determined at different concentrations (I: 5.10, 51.0 and $510 \mathrm{ng} / \mathrm{ml}$; II: $5.30,53.0$ and 530 $\mathrm{ng} / \mathrm{ml})$. The detection limit was defined as the peak signal of I or II equal to three times the average noise level.

\section{Stability studies}

The stability of I has been investigated at $22^{\circ} \mathrm{C}$ in aqueous buffer solutions ( $0.01 \mathrm{M}$ phosphate) with $\mathrm{pH}$ values of $3.0,4.0,5.0,6.0,7.0$ and 8.0. The reactions were initiated by spiking $3.0 \mathrm{ml}$ of pre-heated buffer solution with $15 \mu \mathrm{l}$. of a stock solution of I in methanol $(5.2 \mathrm{mg}$ in $100 \mathrm{ml})$. Periodically, 25- $\mu$ l samples were withdrawn and immediately analyzed by HPLC.

The chemical stabilities of I and II in plasma samples have been determined at 4 and $22^{\circ} \mathrm{C}$. For these experiments $10.0 \mathrm{ml}$ of blank plasma were spiked with $10 \mu \mathrm{l}$ of a stock solution of I or II in methanol to achieve a final drug concentration of $50 \mathrm{ng} / \mathrm{ml}$. At regular time intervals, samples were withdrawn and analyzed with the described HPLC assay. The chemical stabilities of I and II in the methanolic plasma extracts were investigated by spiking plasma samples with the analytes in different ratios (I $100 \%$, II $0 \%$; I $50 \%$, II $50 \%$; I $20 \%$, II $80 \%$, I $5 \%$, II $95 \%$ ); the total drug concentration was $50 \mathrm{ng} / \mathrm{ml}$. The plasma samples were processed as described under Sample pretreatment and the methanolic extracts were analyzed immediately and after a storage period of one month at $-30^{\circ} \mathrm{C}$. The results of the stability studies are expressed as percentages of the initial concentrations of I or II remaining.

\section{Pharmacokinetics}

Rats (WAG/Rij; weight 260 g) received 3.8 $\mathrm{mg} / \mathrm{kg}$ I dissolved in $0.5 \mathrm{ml}$ of PET (polyethyleneglycol-ethanol-polysorbatum $80,6: 10: 1$, $\mathrm{v} / \mathrm{v} / \mathrm{v}$ ) formulation and diluted with $0.5 \mathrm{ml}$ of saline. Compound I was given as a rapid intravenous bolus injection in the tail. At appropriate time intervals blood samples of $300 \mu \mathrm{l}$ were withdrawn from the carotid artery, collected in Ep- 
pendorf cups containing $10 \mu \mathrm{l}$ of heparin solution (equivalent to 50 I.U.) and immediately centrifuged ( $2 \mathrm{~min}$ at $2500 \mathrm{~g}$ ) to obtain the plasma fraction. An aliquot of $100 \mu \mathrm{l}$ was then processed further with $400 \mu \mathrm{l}$ of cold methanol as described under Sample pretreatment. The experiments were performed without anaesthetic.

\section{RESULTS AND DISCUSSION}

An intact lactone moiety of I is of paramount importance for the biological activity of this antitumour agent. Hydrolysis of this function leads to the formation of the corresponding carboxylic acid (II), in a pH-dependent equilibrium; II is only minimally active on topoisomerase I. It is obvious that knowledge on the presence of both species in biological samples is essential for the correct interpretation of pharmacokinetic-pharmacodynamic data of this class of compounds. A bioanalytical assay is, therefore, required which is capable of determining I and II selectively and preferably in a single run. In the HPLC method described by Loh and Ahmed [12] the biological samples are diluted with acetonitrile and after vortex-mixing and centrifugation, the supernatant is acidified to $\mathrm{pH} 2$ after which $\mathrm{I}$ is isolated by a two-fold liquid-liquid extraction with ethyl acetate. This assay is laborious and non-selective as it determines only total drug levels (as I) with no information about the separate concentrations of I and II. The assay presented here includes the simultaneous and selective determination of I and II.

\section{Chromatography and detection}

Various chromatographic systems were tested, including the system we used earlier for the bioanalysis of the camptothecin analogue topotecan and its lactone ring-opened form [14]. This system was, however, not useful as I and II eluted near the solvent front. An optimal system was achieved with a $\mathrm{C}_{18}$ column and a mobile phase comprising a mixture of methanol and phosphate buffer $\mathrm{pH} 6.5$ to which an ion-pairing agent was added to give the carboxylate form II sufficient retention (Fig. 2). A pH value of 6.5 was chosen

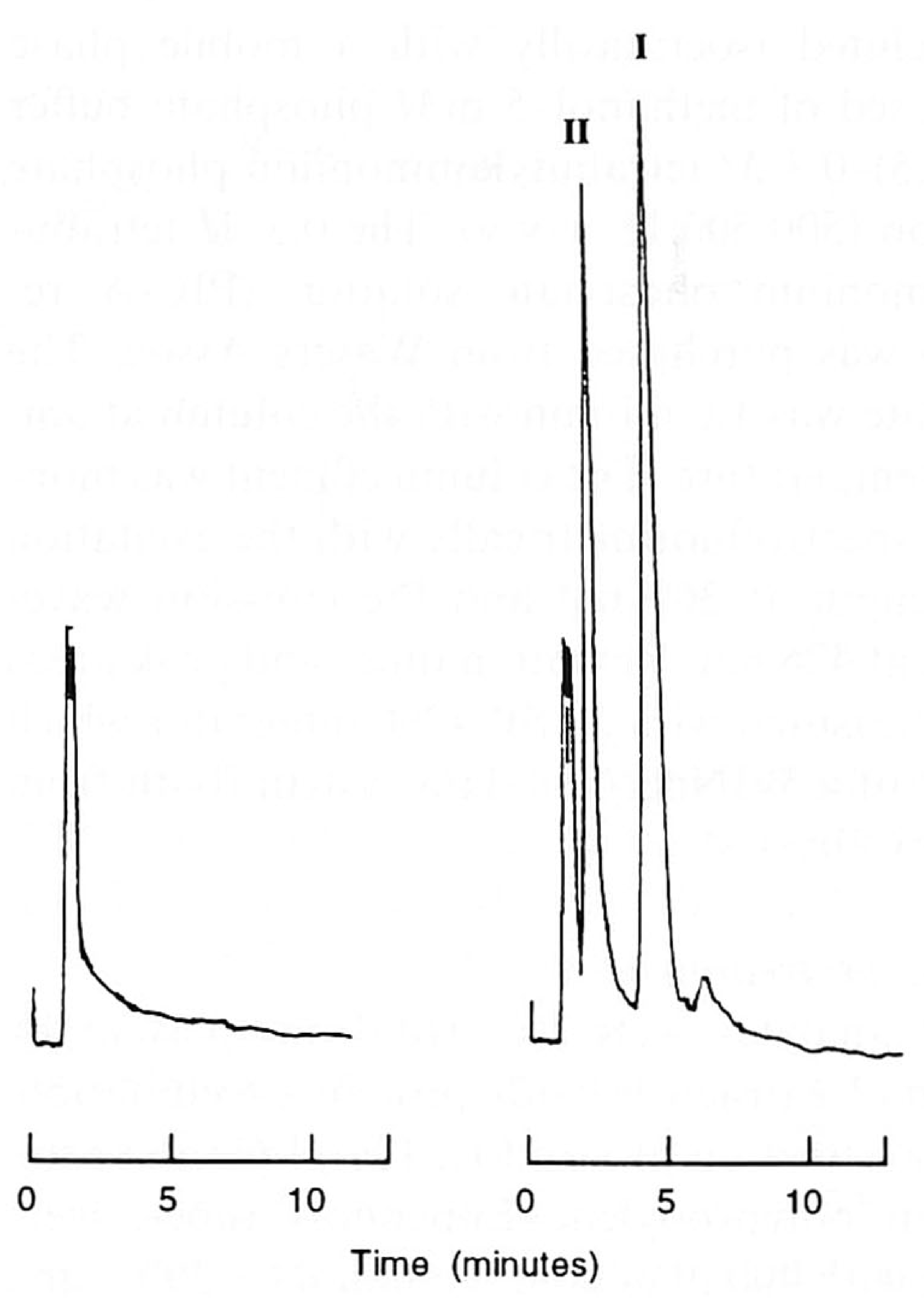

Fig. 2. HPLC of a blank (left) and rat plasma (right) sample 20 min after the administration of I. Drug concentrations: $\mathrm{I}=84$ $\mathrm{ng} / \mathrm{ml} ; \mathrm{II}=204 \mathrm{ng} / \mathrm{ml}$.

for the mobile phase because at this $\mathrm{pH}$ the rates of the forward and reverse reactions of I and II during an analytical HPLC run are relatively low.

The camptothecins show native fluorescence which can be utilized for the detection in HPLC. On-line scanning experiments provided the optimal excitation (369 $\mathrm{nm}$ ) and emission (426 nm) wavelengths in the mobile phase.

\section{Chemical stability of I and II and sample pretreat- ment}

In Fig. 3 the stability of $\mathrm{I}$ in aqueous buffer solutions is given. At acidic $\mathrm{pH}$, compound $\mathrm{I}$ is stable and largely exists in the lactone form whereas under basic conditions it is converted to the carboxylate form. The reactions are reversible. At $\mathrm{pH}$ values $<5$, compound II is rapidly converted into I while at $\mathrm{pH}>8$, compound I hydrolyses almost instantaneously to give the carboxylate form (Fig. 1). At $\mathrm{pH}$ values between 


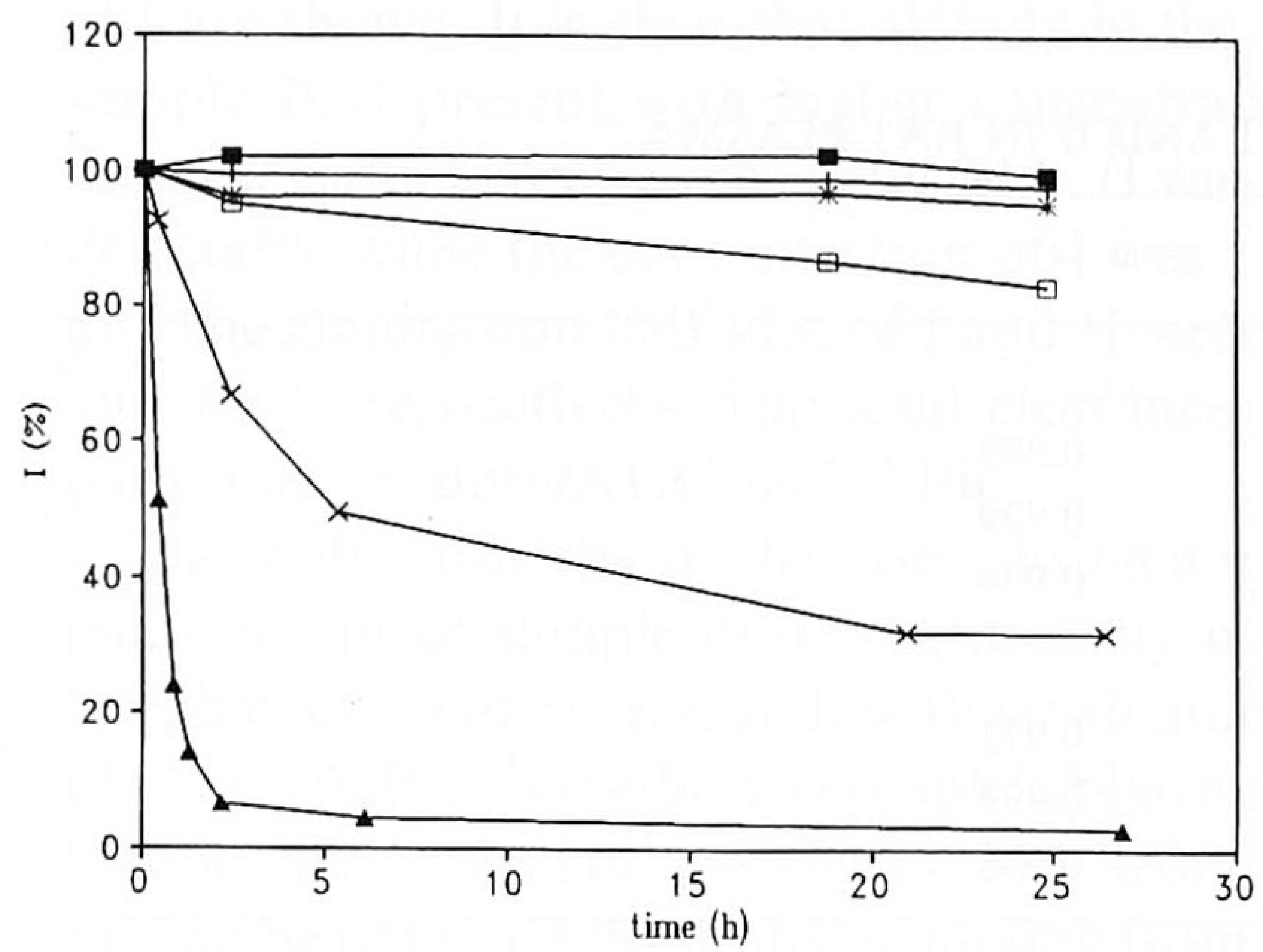

Fig. 3. Chemical stability of $I$ in aqueous buffer solutions. ( $\mathrm{pH} 3.0 ;(+) \mathrm{pH} 4.0 ;(*) \mathrm{pH} 5.0 ;(\square) \mathrm{pH} 6.0 ;(\times) \mathrm{pH} 7.0 ;(\boldsymbol{\Delta}) \mathrm{pH}$ 8.0 .

5 and 8 , an equilibrium is reached with a $\mathrm{I} / \mathrm{II}$ ratio which is dependent upon the $\mathrm{pH}$; the $\mathrm{pH}$ also determines the rate by which the equilibrium is reached. A more detailed study on the kinetics and mechanisms of the hydrolysis of the lactone function in I was recently published [11].

The chemical stabilities of I and II in plasma are also limited, as shown in Fig. 4. In plasma samples spiked with I and stored at 4 or $22^{\circ} \mathrm{C}$, the analyte is rapidly converted into II. After $15 \mathrm{~min}$ at $22^{\circ} \mathrm{C}, 54 \%$ of the initial concentration of I remains and at $4{ }^{\circ} \mathrm{C}, 75 \%$. The ring-opened form is relatively stable under these conditions. The $\mathrm{pH}$ of plasma is around 7.4 and explains the instability of I here. These experiments demonstrate the importance of handling the plasma samples before analysis. For topotecan we found that when

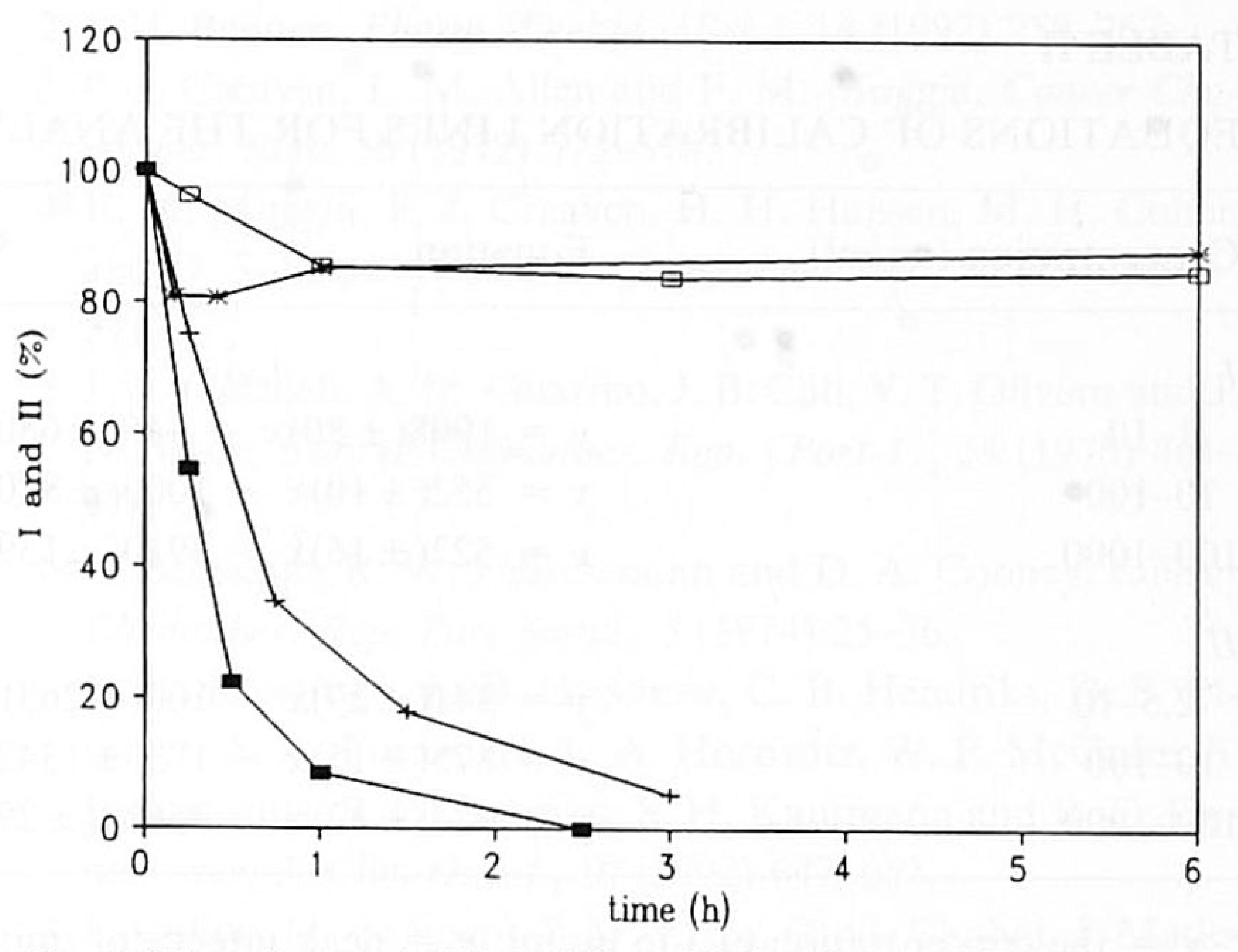

Fig. 4. Chemical stabilities of $\mathrm{I}$ and II in plasma. (回) I at $22^{\circ} \mathrm{C}$; $(+)$ I at $4^{\circ} \mathrm{C} ;(*)$ II at $22^{\circ} \mathrm{C} ;(\square)$ II at $4^{\circ} \mathrm{C}$.

plasma is deproteinated with cold methanol $\left(-30^{\circ} \mathrm{C}\right)$ the resulting extract is stable at $-30^{\circ} \mathrm{C}$ [14].

Methanolic extracts of plasma samples spiked with I or II and processed as described are not stable when stored at 4 or $21^{\circ} \mathrm{C}$. On the other hand the methanolic extracts (total drug concentration $50 \mathrm{ng} / \mathrm{ml}$ with $\mathrm{I} / \mathrm{II}$ ratios from 100:0 to 5:95) could be stored at $-30^{\circ} \mathrm{C}$ for at least one month. After this period the percentages of the initial concentrations of I and II were $100.8 \pm$ $5.3 \%(n=9)$ and $103.0 \pm 10 \%(n=9)$, respectively. It is, therefore, recommended that after sampling the blood in a heparin tube it is immediately centrifuged $(2 \mathrm{~min}, 2500 \mathrm{~g}$ ) to yield the plasma that is treated with cold methanol. The methanolic extracts must be analyzed directly or can

TABLE I

RECOVERIES OF I AND II FROM RAT PLASMA

\begin{tabular}{|c|c|c|c|c|c|c|c|}
\hline \multicolumn{2}{|c|}{ Concentration $(\mathrm{ng} / \mathrm{ml})$} & \multicolumn{3}{|l|}{ I } & \multicolumn{3}{|l|}{ II } \\
\hline I & II & $\begin{array}{l}\text { Recovery } \\
(\%)\end{array}$ & $\begin{array}{l}\text { R.S.D. } \\
(\%)\end{array}$ & $n$ & $\begin{array}{l}\text { Recovery } \\
(\%)\end{array}$ & $\begin{array}{l}\text { R.S.D. } \\
(\%)\end{array}$ & $n$ \\
\hline 5.1 & 5.3 & 100.3 & 5.5 & 3 & 83.8 & 8.3 & 5 \\
\hline 51.0 & 53.0 & 94.6 & 2.7 & 5 & 78.1 & 7.2 & 5 \\
\hline 510.0 & 530.0 & 97.5 & 2.3 & 5 & 84.2 & 6.1 & 5 \\
\hline
\end{tabular}


TABLE II

EQUATIONS OF CALIBRATION LINES FOR THE ANALYSIS OF I AND II IN RAT PLASMA

\begin{tabular}{lll}
\hline Concentration $(\mathrm{ng} / \mathrm{ml})$ & Equation & $r^{2}$ \\
\hline$I$ & & \\
$1-10$ & $y=1908( \pm 80) x-246( \pm 680)^{a}$ & 0.993 \\
$10-100$ & $y=552( \pm 10) x-1000( \pm 870)^{a}$ & 0.999 \\
$100-1000$ & $y=522( \pm 16) x-2910( \pm 13900)^{a}$ & 0.996 \\
$I I$ & & \\
$2.5-10$ & $y=341( \pm 29) x-100( \pm 263)^{b}$ & 0.973 \\
$10-100$ & $y=875( \pm 15) x-173( \pm 1342)^{c}$ & 0.999 \\
$100-1000$ & $y=974( \pm 32) x-35610( \pm 29842)^{c}$ & 0.996
\end{tabular}

${ }^{a} x=$ the concentration of $\mathrm{I}$ in $\mathrm{ng} / \mathrm{ml} ; y=$ peak integrator units.

${ }^{b} x=$ the concentration of II in $\mathrm{ng} / \mathrm{ml} ; y=$ peak heights.

c $x=$ the concentration of $\mathrm{II}$ in $\mathrm{ng} / \mathrm{ml}: y=$ peak integrator units.

TABLE III

ACCURACY AND PRECISION FOR THE BIOANALYSIS OF I AND II IN RAT PLASMA

\begin{tabular}{lllll}
\hline $\begin{array}{l}\text { Theoretical } \\
\text { concentration } \\
(\mathrm{ng} / \mathrm{ml})\end{array}$ & $\begin{array}{l}\text { Mean measured } \\
\text { concentration } \\
(\mathrm{ng} / \mathrm{ml})\end{array}$ & $\begin{array}{l}\text { Accuracy } \\
(\%)\end{array}$ & $\begin{array}{l}\text { R.S.D. } \\
(\%)\end{array}$ & $n$ \\
\hline$I$ & & & & \\
5.10 & 5.32 & 104 & 5.3 & 3 \\
51.0 & 51.0 & 100 & 2.6 & 5 \\
510 & 538 & 105 & 2.2 & 5 \\
$I I$ & & & 5 \\
5.30 & 5.60 & 106 & 8.8 & 5 \\
53.0 & 52.8 & 99.6 & 7.2 & 5 \\
\hline
\end{tabular}

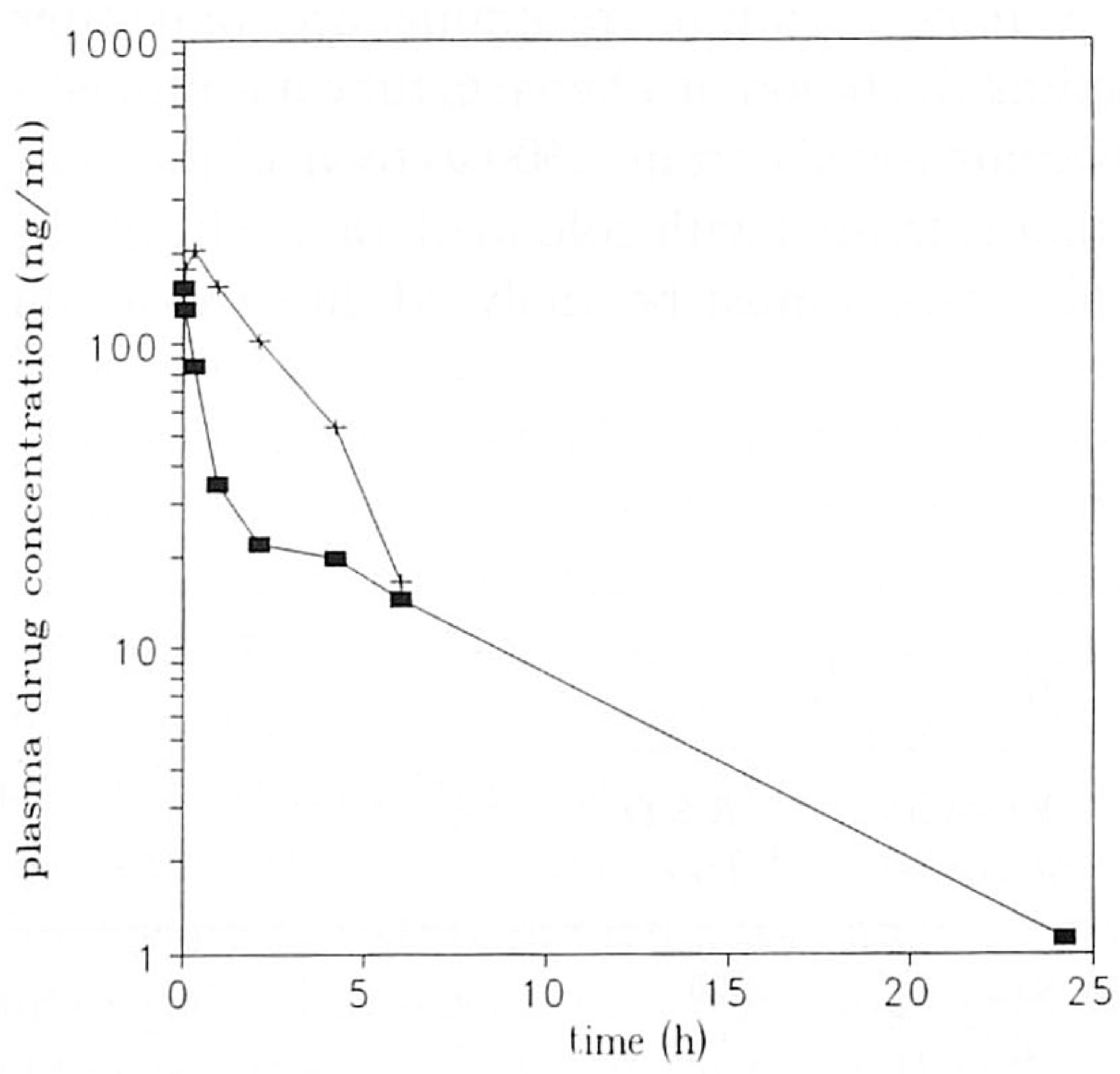

Fig. 5. Typical plasma concentration-time curves of I ( $\boldsymbol{\square})$ and II $(+)$ obtained after a rapid intravenous bolus injection of 3.8 $\mathrm{mg} / \mathrm{kg}$ in the tail of a rat. be stored for at least one month at $-30^{\circ} \mathrm{C}$. When the methanolic samples are taken from the freezer they should be analyzed immediately.

\section{Validation}

Validation parameters in terms of linearity, recovery, accuracy and precision are listed in Tables I, II and III. The detection limit for I is 0.2 $\mathrm{ng} / \mathrm{ml}$ and for II $1.0 \mathrm{ng} / \mathrm{ml}$ using only a $100-\mu \mathrm{l}$ plasma sample. The molar fluorescence intensity of II is a factor of 5 less than that of I, which explains the difference between the detection limits.

\section{Pharmacokinetics}

In Fig. 5 the plasma concentration-time curves for I and II after an intravenous bolus injection 
of I are shown. It is clear that already in the first sample II is present with higher concentrations than the parent compound. After $24 \mathrm{~h}$, II was not detectable while the concentration of I was $1 \mathrm{ng} /$ $\mathrm{ml}$. The elimination half-lifes of I and II were 4.9 and $1.8 \mathrm{~h}$, respectively. The total clearance of $\mathrm{I}$ (clearance $=$ dose $/$ AUC) is $3.7 \mathrm{l} / \mathrm{h}$.

The high sensitivity of the assay, using a minimal amount of sample only, is extremely useful for pharmacokinetic research with small animals like rats. With this method a complete pharmacokinetic curve of eight samples in $24 \mathrm{~h}$ from one rat can be obtained. Repeated sampling from one animal is attractive as it eliminates inter-individual differences and limits the number of animals required per study.

\section{CONCLUSIONS}

A simple and sensitive HPLC method is presented for the simultaneous determination of camptothecin and its lactone ring-opened form. The assay requires only a plasma sample volume of $100 \mu \mathrm{l}$ and is suitable for pharmacokinetic research.

\section{REFERENCES}

1 M. E. Wall, M. C. Wani, C. E. Cook, K. H. Palmer, A. T. McPhail and G. A. Sim, J. Am. Chem. Soc., 88 (1966) 38883890 .
2 J. H. Beijnen, Pharm Weekbl. (Sci.), 14 (1992) 258-267.

3 P. J. Creaven, L. M. Allen and F. M. Muggia, Cancer Chemother. Rep., 56 (1972) 573-578.

4 F. M. Muggia, P. J. Creaven, H. H. Hansen, M. H. Cohen and O. S. Selawry, Cancer Chemother. Rep., 56 (1972) 515521.

5 J. A. Gottlieb, A. M. Guarino, J. B. Call, V. T. Olivero and J. B. Block, Cancer Chemother. Rep. (Part 1), 54 (1970) 461470.

6 U. Schaeppi, R. W. Fleischmann and D. A. Cooney, Cancer Chemother. Rep. Part Suppl., 5 (1974) 25-36.

7 E. K. Rowinsky, L. B. Grochow, C. B. Hendriks, D. S. Ettinger, A. A. Forastiere, L. A. Horowitz, W. P. McGuire, S. E. Sartorius, B. G. Lubejko, S. H. Kaufmann and R. C. Donehower, J. Clin. Oncol., 10 (1992) 647-653.

8 S. Culine, M. de Forni, J. M. Extra, G. G. Chabot, I. Madelaine, P. Hérat, R. Bugat, M. Marty and A. Mathieu-Boué, Proc. Am. Assoc. Clin. Oncol., 11 (1992) 110.

9 B. C. Giovanella, M. E. Wall, M. C. Wani, R. Silber, J. S. Stehlin, H. Hochster and M. Potmesil, Proc. Am. Assoc. Cancer Res., 33 (1992) 432.

10 R. P. Hertzberg, M. J. Caranfa, K. G. Holden, D. R. Jakes, G. Gallagher, M. R. Mattern, S. M. Mong, J. O. Bartus, R. K. Johnson, W. D. Kingsbury, J. Med. Chem., 32 (1989) 715-720.

11 J. Fassberg and V. J. Stella, J. Pharm. Sci., 81 (1992) 676684.

12 J.-P. Loh and A. E. Ahmed, J. Chromatogr., 530 (1990) $367-$ 376.

13 L. G. Hart, J. B. Call and V. T. Olivero, Cancer Chemother. Rep. (Part 1), 53 (1969) 211-214.

14 J. H. Beijnen, B. R. Smith, W. J. Keijer, R. van Gijn, W. W. ten Bokkel Huinink, L. Th. Vlasveld, S. Rodenhuis and W. J. M. Underberg, J. Pharm. Biomed. Anal., 8 (1990) 789-794. 